\author{
O. Yu. Maslov, S. V. Kolisnyk, T. A. Kostina, Z. V. Shovkova, \\ E. Yu. Ahmedov, M. A. Komisarenko
}

National University of Pharmacy of the Ministry of Health of Ukraine, Ukraine 53, Pushkins'ka str., Kharkiv, 61002. E-mail: alexmaslov392@gmail.com

\title{
Validation of the alkalimetry method for the quantitative determination of free organic acids in raspberry leaves
}

Organic acids are a large group of biologically active compounds that perform important functions in the plant organism. Moreover, all plants, regardless of the species and family, contain organic acids to a small or large extent as organic acids belong to intermediate metabolites arising from the oxidation of proteins and amino acids, fats and carbohydrates.

Aim. To validate the method of alkalimetry proposed with potentiometric detection of the end-point for the quantitative determination of free organic acids in raspberry leaves.

Results and discussion. The method proposed was validated according to the International Conference on Harmonization $(\mathrm{ICH})$ guidelines. The linearity was in the concentration range of $40-200 \%\left(r^{2}=0.9991\right)$. The percentage of recovery was found to be in the range of $98.77-102.48 \%$. The repeatability and intermediate precision were $1.58 \%$ and $1.74 \%$, respectively. The method is accurate and reliable, with the relative standard deviation of less than $2 \%$.

Experimental part. Leaves of raspberry were collected in the Kharkiv region during the period of full ripening. A Hanna $2550 \mathrm{pH}$-meter with a HI 1131P potentiometric electrode was used for alkalimetric titration of free organic acids. The titration was carried out using a microburette with Class A accuracy.

Conclusions. The alkalimetry method for the quantitative determination of free organic acids in raspberry leaves has been proposed and validated according to the following parameters: specificity, linearity, accuracy, repeatability, intermediate precision, robustness. It has been confirmed that the method is simple, reliable, accurate and cost-effective.

Key words: raspberry; leaves; free organic acids; alkalimetry; validation

О. Ю. Маслов, С. В. Колісник, Т. А. Костіна, З. В. Шовкова, Е. Ю. Ахмедов,

М. А. Комісаренко

Національний фрармацевтичний університет Міністерства охорони здоров'я України, Україна

Валідація алкаліметричної методики кількісного визначення вільних органічних кислот у листі малини

Органічні кислоти - велика група біологічно активних сполук, які виконують важливі фрункції в обміні речовин рослин. Усі рослини, незалежно від виду та родини, містять органічні кислоти в невеликій або значній кількості, бо ці речовини належать до проміжних метаболітів, що утворюються в результаті окиснення білків, амінокислот, жирів та вуглеводів.

Мета. Валідувати запропоновану алкаліметричну методику з потенціометричним виявленням кінцевої точки титрування для кількісного визначення вільних органічних кислот у листі малини.

Результати та їх обговорення. Запропонований метод валідовано згідно з директивою International Conference on Harmonization. Лінійність зберігалася в діапазоні концентрацій 40-200\% $\left(\mathrm{r}^{2}=0,9991\right)$. Визначено, що відсоток відновлення становить 98,77-102,48\%, повторюваність та проміжна точність - 1,58\% та 1,74\% відповідно. Метод характеризується як точний і надійний, має відносне стандартне відхилення менше $2 \%$.

Експериментальна частина. Листя малини в період повного дозрівання збирали в Харківській області. Для алкаліметричного титрування вільних органічних кислот використовували рН-метр Нanna 2550 з потенціометричним електродом HI 1131P. Титрування проводили мікробюреткою з класом точності А.

Висновки. Розроблену титриметричну методику кількісного визначення вільних органічних кислот у листі малини валідовано за такими параметрами: специфічність, лінійність, точність, збіжність, внутрішня прецизійність, робасність. Підтверджено, що метод є простим, надійним, точним та економічно вигідним.

Ключові слова: малина; листя; вільні органічні кислоти; алкаліметрія; валідація

Copyright $\odot 2021$, O. Yu. Maslov, S. V. Kolisnyk, T. A. Kostina, Z. V. Shovkova, E. Yu. Ahmedov This is an open access article under the CC BY license (http://creativecommons.org/licenses/by/4.0)

A variety of biologically active compounds have been found in raspberry leaves, including flavonoids, phenolic acids, organic acids, ellagitannins, gallotannins and proanthocyanidins [1,2]. There is a rather high interest in determining the amount of organic acids in raspberry leaves in literary sources $[3,4]$. According to these studies, the total amount of organic acids is relatively high and ranges from 1.1 to $2.3 \%$; it makes raspberry leaves a promising raw material of organic acids $[5,6]$.

Organic acids are a group of biologically active compounds with a wide spectrum of the pharmaco- logical activity. They reveal vitamin properties, possess the choleretic effect, and normalize the activity of the digestive system. Organic acids regulate the secretion of the bile and pancreatic juice, improve appetite, possess bactericidal properties and reduce putrefactive processes in the body [7].

Nowadays there are various analytical methods for determining organic acids such as titration, ion chromatography [8], high-performance liquid chromatography-ultraviolet detection (HPLC-UV) [9], capillary electrophoresis [10], gas chromatography (GC) [11] and thin-layer chromatography [12]. 
Although HPLC-UV and GC have been proposed for the determination of organic acids before, they require high skillful analysts and expensive instruments. In addition, most of the procedures previously described require expensive instrumental setup. That is why in the current work the method of alkalimetry with potentiometric detection of the end-point was chosen for determining organic acids in raspberry leaves as it is simple, reliable, rapid and economical. Thus, the aim of the study was to validate the method proposed for the quantitative determination of free organic acids in raspberry leaves.

\section{Experimental part}

The study object was raspberry leaves collected in the Kharkiv region during the period of full ripening, according to the rules of harvesting this type of plant. Drying of leaves was carried out at a temperature of $60^{\circ} \mathrm{C}$ to a residual humidity of not more than $20 \%$. A Hanna $2550 \mathrm{pH}$ meter with HI 1131P potentiometric electrode was used in the study. All titrations were carried out manually. Free organic acids were titrated using a microburette with Class A accuracy. Weighing was carried out using an AN100 digital analytical balance (AXIS, Ukraine) with $\mathrm{d}=0.0001 \mathrm{~g}$.

Citric acid was purchased from Sigma Aldrich ( $\geq 98 \%$ ), $\mathrm{NaOH}$ was of analytical grade. In order to prepare $\mathrm{NaOH}$ solution with the concentration of $0.05 \mathrm{M}$, $1.0 \mathrm{~g}$ of $\mathrm{NaOH}$ was dissolved in distilled water. The solution was diluted to $250 \mathrm{~mL}$ with the same water and standardized.

The procedure of the quantitative determination of free organic acids in raspberry leaves. Place $2.0 \mathrm{~g}$ (accurate weight) of the crushed raw material in a $100 \mathrm{~mL}$ flask with a ground glass joint, then pour $40 \mathrm{~mL}$ of distilled water in the flask, equip it with a condenser and keep the flask for $2 \mathrm{~h}$ on a boiling water bath. After cooling quantitatively transfer the solution into a $50 \mathrm{~mL}$ volumetric flask and dilute to the volume (solution A).

Place $5.00 \mathrm{~mL}$ of the solution A in a $100 \mathrm{~mL}$ flask, and add $45.0 \mathrm{~mL}$ of distilled water with the subsequent titration of the solution by $0.05 \mathrm{M}$ sodium hydroxide. After adding each portion of $0.05 \mathrm{M}$ sodium hydroxide mix the solution thoroughly, and record the electrode potential.

The blank experiment was also performed. According to it, the blank volume of $0.05 \mathrm{M}$ sodium hydroxide was $0.03 \mathrm{~mL}$.

The content of organic acids in the solution was calculated from the value of the equivalent volume of the titrant. The equivalent volume of the titrant was determined by a differential curve constructed in the $\Delta \mathrm{E} / \Delta \mathrm{V}-\mathrm{V}$ coordinates. The equivalence point was fixed at the maximum of the differential curve. The perpendicular line was dropped to the horizontal axis (the volume of the titrant) through the maximum, and the volume of the titrant spent on titration was determined (Fig. 1).

The content of free organic acids (X, \%) with reference to citric acid in the completely dry raw material was calculated by the following formula:

$$
\mathrm{X}=\frac{\left(V_{e q}-V_{x}\right) \cdot 0.0032 \cdot 50 \cdot 100 \cdot 100 \cdot K}{m \cdot 5 \cdot(100-W)},
$$

where: 0.0032 - is the amount of citric acid equivalent to $1 \mathrm{~mL}$ of sodium hydroxide solution $(0.05 \mathrm{~mol} / \mathrm{L})$, g; $V_{e q}$ - is the volume of sodium hydroxide solution $(0.05 \mathrm{~mol} / \mathrm{L})$ used for titration, $\mathrm{mL} ; V_{\mathrm{y}}$ - is volume of sodium hydroxide solution $(0.05 \mathrm{~mol} / \mathrm{L})$ spent for titration in the blank experiment, $\mathrm{mL}$; $\mathrm{m}$ - is the mass of the raw material used, g; $K$ - is the correction coefficient for $0.05 \mathrm{~mol} / \mathrm{L}$ sodium hydroxide solution; $\mathrm{W}$ - is the loss on drying of the raw material, $\%$.

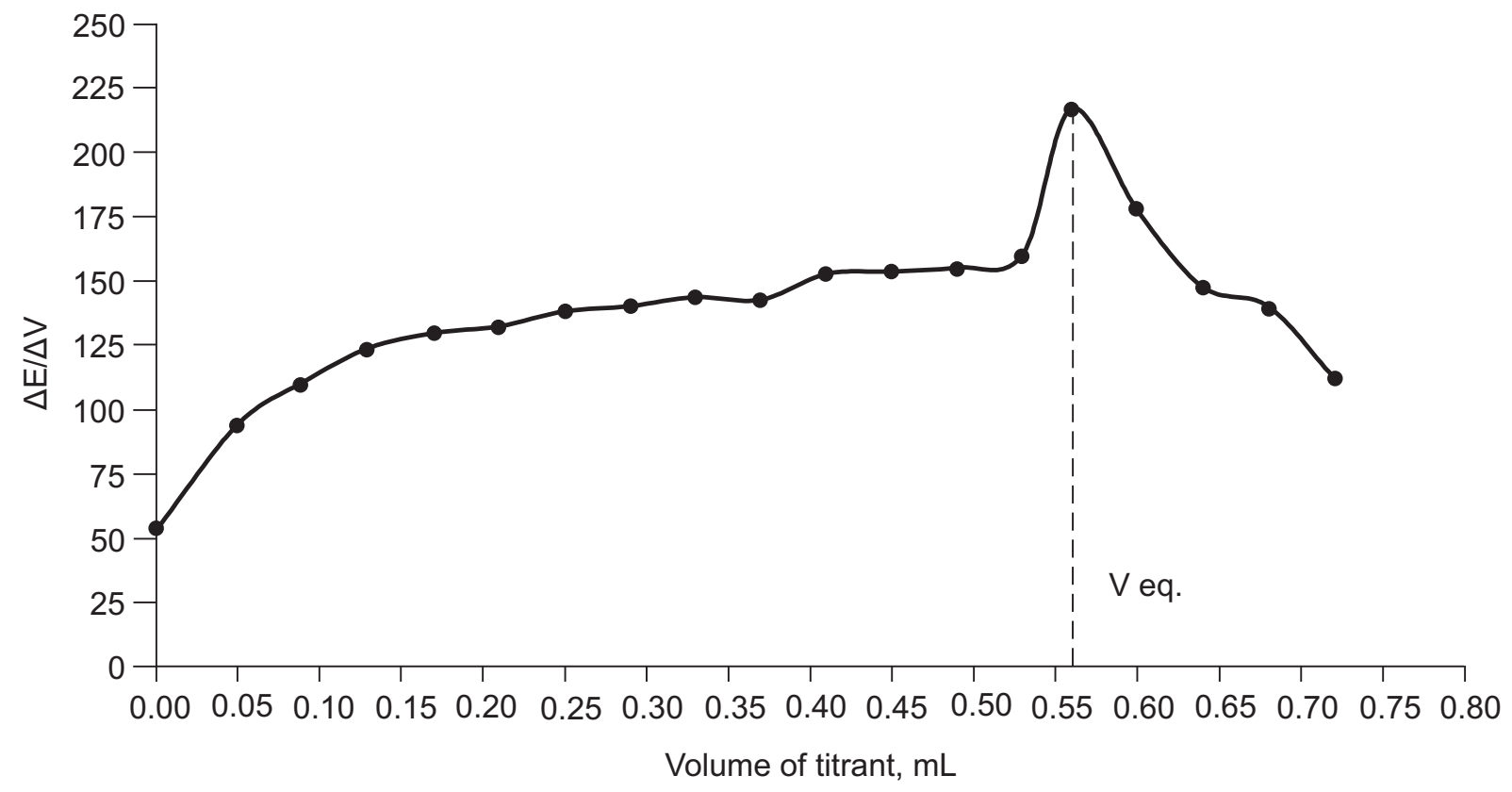

Fig. 1. The potentiometric titration curve of determination total free organic acids in raspberry leaves 


\section{Validation}

Validation of the alkalimetric method for the quantitative determination of the amount of free organic acids in raspberry leaves by potentiometric titration was performed according to the International Conference on Harmonization (ICH). The titrimetric method proposed was validated by the following parameters: specificity, accuracy, linearity, repeatability, intermediate precision, robustness.

The specificity of the method was studied by potentiometric titration of the solvent.

The accuracy was verified by the method of additives in a triplicate analysis of three levels of concentration of organic acids corresponding to $40,60,80 \%$ of the working concentrations of organic acids. The standard solution of citric acid was prepared as follows: $0.076 \mathrm{~g}$ (accurate weight) of citric acid was placed in a $200.00 \mathrm{~mL}$ volumetric flask, and the solution was diluted to the volume with distilled water. Then an aliquot of the resulting standard solution of 2.00, 3.00, $4.00 \mathrm{~mL}$ was taken and placed in a $100.0 \mathrm{~mL}$ flask. After that $5.00 \mathrm{~mL}$ of the extract obtained from raspberry leaves was added to the flask, then $45.0 \mathrm{~mL}$ of distilled water was added, and the solution was titrated. The evaluation criterion in determining the accuracy was the value of the relative standard deviation (RSD), which according to the requirements should be not more than $2 \%$, and the percentage of recovery should be from 95 to $105 \%$.

The linearity of the method was studied at 9 concentration levels $(40,60,80,100,120,140,160,180,200 \%)$ of the theoretical content of the total amount of free organic acids (calculated with reference to citric acid, \%) in raspberry leaves. In order to evaluate linearity of the method, different aliquots of the extract were taken $(2.00 ; 3.00 ; 4.00 ; 5.00 ; 6.00 ; 7.00 ; 8.00 ; 9.00 ; 10.00 \mathrm{~mL})$. After that each aliquot was placed in a $100.0 \mathrm{~mL}$ flask and diluted to the volume with distilled water. The quantitative content of the total amount of free organic acids (calculated with reference to citric acid, \%) in raspberry leaves in the solutions obtained was then determined according to the alkalimetry method of titration. The linearity was assessed by a linear relationship between the concentration of the total amount of free organic acids and the equivalent volume of the titrant, as well as the correlation coefficient calculated. The linear regression was calculated by the method of least squares to obtain the regression equation and determine the correlation coefficient $\left(r^{2}\right)$. According to the requirements of ICH, the value of the correlation coefficient when studying the linearity of the analytical method for determining the quantitative content of the active substance should be $\geq 0.999$.

The repeatability of the method was checked by preparing an aqueous extract of raspberry leaves from 6 portions of the raw material within a short period of time using the same set of reagents and with the participation of the same analyst. The intermediate precision was determined as described above in the same laboratory, but in different days. The acceptance criterion is expressed by the value of the relative standard deviation, which should not exceed $2 \%$.

The robustness of the potentiometric procedure was tested at $100 \%$ concentration of free organic acids with the participation of two different analysts and two different burettes. The acceptance criterion is expressed by the value of the relative standard deviation, which should not exceed $2 \%$.

The statistical processing of experimental data obtained was performed in accordance with the monograph «Statistical analysis of the results of a chemical experiment» of the State Pharmacopeia of Ukraine.

\section{Results and discussion}

When studying the specificity of the method, it was shown that the solvent used in the samples preparation and the probable impurities did not affect the result of the quantification of the amount of free organic acids in raspberry leaves (Table 1).

Linearity was proven in the concentration range from $40 \%$ to $200 \%$. A calibration curve of the dependence of the equivalent volume of the titrant values on the volume of aliquots of the extract from raspberry leaves was plotted (Fig. 2). The regression equation of the curve had the following form: $y=0.1667 x-0.2722$. The value of the correlation coefficient ( $\mathrm{r}^{2}$ ) was equal to 0.9991 (Fig. 2).

When testing the method for the quantitative determination of the amount of free organic acids by linearity parameters it was found that the correlation coefficient $\left(\mathrm{r}^{2}\right)$ was 0.9991 . Therefore, there is a direct linear relation between the equivalent volume of the titrant and the concentration of organic acids.

\section{Table 1}

The results of the titration to prove the specificity of the method developed $(n=3, P=95 \%)$

\begin{tabular}{|c|c|c|}
\hline $\mathrm{V}_{\text {titrant }^{\prime}} \mathrm{mL}$ & $\begin{array}{c}\text { Content of organic } \\
\text { acids, } \%\end{array}$ & Statistical analysis \\
\hline \multicolumn{3}{|c|}{ Blank experiment (titration of distilled water) } \\
\hline 0.03 & 0.05 & \multirow{3}{*}{$\begin{array}{c}0.045 \pm 0.02 \% \\
s_{x}=0.0014\end{array}$} \\
\hline 0.02 & 0.035 & \\
\hline 0.03 & 0.05 & \\
\hline \multicolumn{3}{|c|}{ Results of titration of the extract from raspberry leaves } \\
\hline 0.57 & 1.00 & \multirow{3}{*}{$\begin{array}{c}1.00 \pm 0.02 \% \\
s_{x}=0.0033\end{array}$} \\
\hline 0.56 & 0.99 & \\
\hline 0.57 & 1.00 & \\
\hline
\end{tabular}




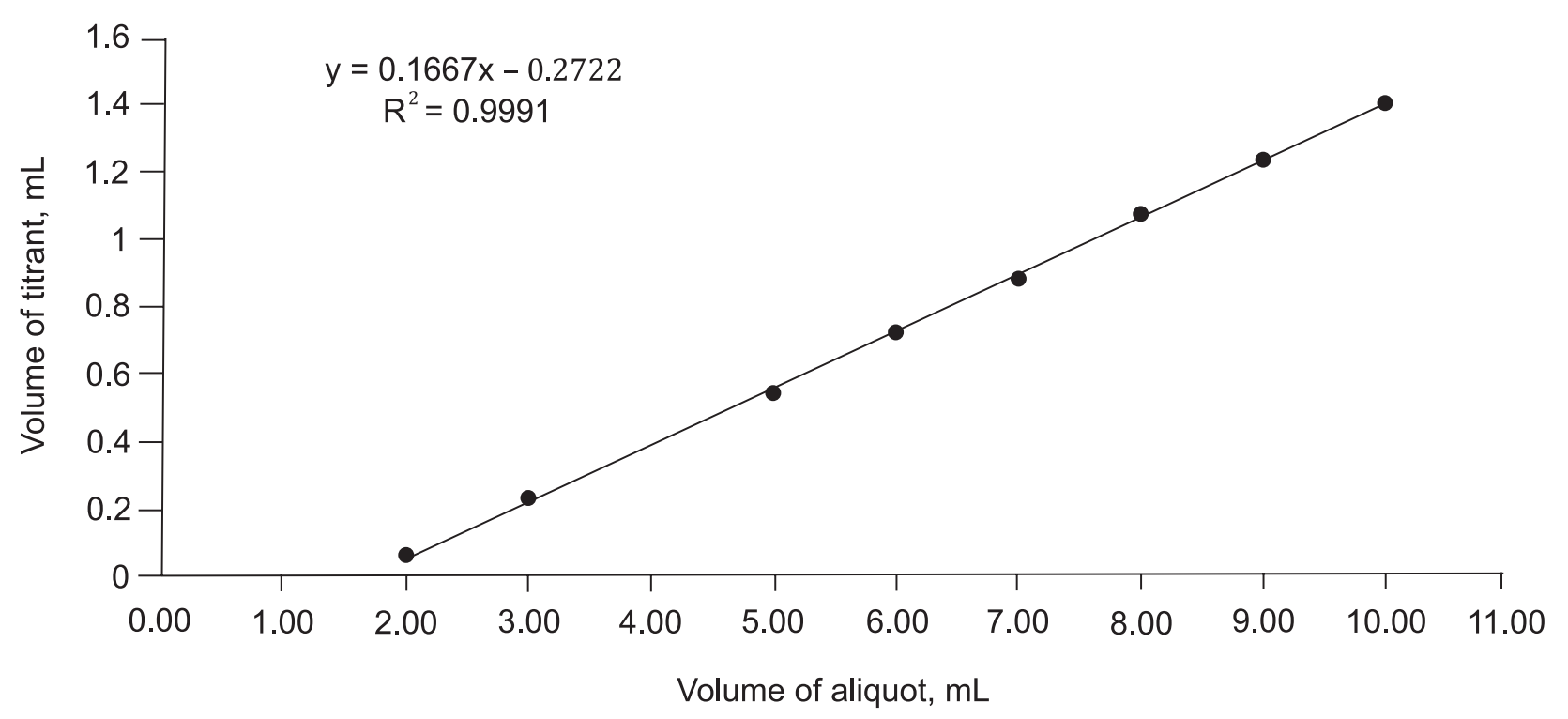

Fig. 2. The calibration curve of the titrant volume vs the volume of an aliquot of the extract prepared

Table 2

Recovery studies by the procedure of standard additions

\begin{tabular}{|c|c|c|c|c|c|c|}
\hline $\begin{array}{l}\text { The amount } \\
\text { present, } g\end{array}$ & $\begin{array}{l}\text { The amount of citric acid } \\
\text { added, } g\end{array}$ & $\begin{array}{l}\text { The amount of organic } \\
\text { acids taken, } g\end{array}$ & $\begin{array}{l}\text { The amount } \\
\text { recovered, } g\end{array}$ & Recovery, \% & $\mathrm{SD}, \%$ & RSD, \% \\
\hline \multirow{3}{*}{0.019} & \multirow{3}{*}{0.0052} & \multirow{3}{*}{0.0242} & 0.024 & 99.17 & \multirow{9}{*}{1.46} & \multirow{9}{*}{1.45} \\
\hline & & & 0.0248 & 102.48 & & \\
\hline & & & 0.0246 & 101.65 & & \\
\hline \multirow{3}{*}{0.019} & \multirow{3}{*}{0.0134} & \multirow{3}{*}{0.0324} & 0.032 & 98.77 & & \\
\hline & & & 0.033 & 101.85 & & \\
\hline & & & 0.0326 & 100.62 & & \\
\hline \multirow{3}{*}{0.019} & \multirow{3}{*}{0.0184} & \multirow{3}{*}{0.0374} & 0.037 & 98.93 & & \\
\hline & & & 0.0372 & 99.47 & & \\
\hline & & & 0.0378 & 101.07 & & \\
\hline
\end{tabular}

Table 3

Repeatability of organic acids in raspberry leaves

\begin{tabular}{|c|c|}
\hline Number of samples & $\begin{array}{c}\text { Content of free } \\
\text { organic acids, \% }\end{array}$ \\
\hline 1 & 0.95 \\
\hline 2 & 0.97 \\
\hline 3 & 0.93 \\
\hline 4 & 0.95 \\
\hline 5 & 0.95 \\
\hline 6 & 0.95 \\
\hline Mean, \% & 0.95 \\
\hline SD & 0.0151 \\
\hline Confidence interval $(\mathrm{P}=95 \%), \%$ & 0.0120 \\
\hline RSD, \% & 1.58 \\
\hline
\end{tabular}

The accuracy of the method was assessed using the percentage of recovery and the relative standard deviation. The percentage of recovery was found to be in the range from 98.77 to $102.48 \%$, and its average value was $100.45 \%$, the value of the relative standard deviation when assessing the correctness of the method was $1.45 \%$ and did not exceed $2 \%$ (Table 2).

The precision of the method was confirmed by repeatability and intermediate precision. The values of RSD for repeatability and intermediate precision were 1.58 and $1.74 \%$, respectively. The RSD values were less than $2 \%$. It proves that the method is precise (Tables 3, 4).

The robustness of the method was determined by changing the analyst and burette. It was found that the RSD values of inter-analyst and inter-burette were 
Intermediate precision of organic acids in raspberry leaves

\begin{tabular}{|c|c|c|}
\hline \multirow{2}{*}{ Number of samples } & \multicolumn{2}{|c|}{ Content of free organic acids, \% } \\
\cline { 2 - 3 } & The first day & The second day \\
\hline 1 & 0.95 & 0.93 \\
\hline 2 & 0.95 & 0.93 \\
\hline 3 & 0.93 & 0.95 \\
\hline 4 & 0.97 & 0.97 \\
\hline 5 & 0.93 & 0.95 \\
\hline 6 & 0.95 & 0.97 \\
\hline Mean, \% & 0.95 & 0.95 \\
\hline SD & 0.0151 & 0.0179 \\
\hline Confidence interval $(\mathrm{P}=95 \%), \%$ & 0.0120 & 0.0143 \\
\hline Mean, \% & 1.59 & 1.88 \\
\hline Mean RSD, \% & & 1.74 \\
\hline
\end{tabular}

Table 5

Robustness of organic acids in raspberry leaves

\begin{tabular}{|c|c|c|c|c|c|c|}
\hline \multirow{2}{*}{$\begin{array}{c}\text { Concentration of } \\
\text { organic acids, \% }\end{array}$} & \multicolumn{3}{|c|}{ Content of free organic acids, \% } & \multicolumn{2}{c|}{ RSD, \% } \\
\cline { 2 - 5 } & The first analyst & $\begin{array}{c}\text { The second } \\
\text { analyst }\end{array}$ & The first burette & $\begin{array}{c}\text { The second } \\
\text { burette }\end{array}$ & Inter-analysts & Inter-burettes \\
\hline 0.95 & 0.95 & 0.95 & 0.97 & 0.93 & & \\
\hline 0.95 & 0.95 & 0.95 & 0.97 & 0.95 & & \multirow{2}{*}{1.37} \\
\hline 0.95 & 0.97 & 0.93 & 0.97 & 0.97 & \\
\hline 0.95 & 0.97 & 0.93 & 0.95 & 0.93 & & \\
\hline 0.95 & 0.93 & 0.93 & 0.95 & 0.95 & & \\
\hline 0.95 & 0.93 & 0.95 & 0.95 & 0.95 & & \\
\hline
\end{tabular}

1.52 and $1.37 \%$, respectively. The RSD values were less than $2 \%$, showing that minor changes in conditions have little effect on the results (Table 5).

\section{Conclusions}

The alkalimetric method for the quantitative determination of free organic acids in the raspberry leaves has been developed and validated according to the following parameters: specificity, linearity, accuracy, repeatability, intermediate precision, robustness. It has been confirmed that the method is simple, reliable, accurate and cost-effective.

Conflict of Interests: the authors have no conflict of interests to declare.

\section{References}

1. Padmanabhan, P.; Correa-Betanzo, J.; Paliyath, G. Berries and Related Fruits. In Encyclopedia of Food and Health; Caballero, B.; Finglas, P. M.; Toldrá, F., Eds. Academic Press: Oxford, 2016; pp 364-371. https://doi.org/10.1016/B978-0-12-384947-2.00060-X.

2. Sariburun, E.; Şahin, S.; Demir, C.; Türkben, C.; Uylaşer, V. Phenolic Content and Antioxidant Activity of Raspberry and Blackberry Cultivars. J. Food Sci. 2010, 75 (4), C328-C335. https://doi.org/10.1111/j.1750-3841.2010.01571.x.

3. Velichko, V. V.; Makarova, D. L. Comparative pharmacognostic analysis of leaves and fruit of raspberry ordinary. Medicine and Education in Siberia 2015, 4.

4. Дергачева, Ж. М.; Гурина, Н. С.; Мушкина, О. В. Фитохимический анализ листьев малины обыкновенной (Rubi Idaeus Folia). Рещепm 2015, 6, 64-74. https://doi.org/10.3390/antiox5020017.

5. Bobinaitė, R.; Viškelis, P.; Venskutonis, P. R., Chapter 29 - Chemical Composition of Raspberry (Rubus spp.) Cultivars. In Nutritional Composition of Fruit Cultivars; Simmonds, M. S. J.; Preedy, V. R., Eds.; Academic Press: San Diego, 2016; pp 713-731. https://doi.org/10.1016/B978-0-12408117-8.00029-5.

6. Ferlemi, A.-V.; Lamari, F. N. Berry Leaves: An Alternative Source of Bioactive Natural Products of Nutritional and Medicinal Value. Antioxidants 2016, 5 (2), 17. https://doi.org/10.3390/antiox5020017.

7. Сергунова, Е. В.; Марахова, А. И.; Аврач, А. С. Методы количественного определения органических кислот в лекарственном растительном сырье и водных извлечениях. Фармация 2013, 4, 8-11.

8. Gu, Y.; Li, J.; Song, W.; Zhang, X. Determination of $\mathrm{C}_{1}-\mathrm{C}_{6}$ organic acids in the products from syngas to olefins by ion chromatography. Chinese journal of chromatography 2014, 32 (2), 204-209. https://doi.org/10.3724/sp.j.1123.2013.09038.

9. Mortera, P.; Zuljan, F. A.; Magni, C.; Bortolato, S. A.; Alarcón, S. H. Multivariate analysis of organic acids in fermented food from reversed-phase high-performance liquid chromatography data. Talanta 2018,178, 15-23. https://doi.org/10.1016/j.talanta.2017.09.005. 
10. Nogueira, T.; Lago, C. L. d. Determination of Ca, K, Mg, Na, sulfate, phosphate, formate, acetate, propionate, and glycerol in biodiesel by capillary electrophoresis with capacitively coupled contactless conductivity detection. Microchem. J. 2011, 99 (2), 267-272. https://doi.org/10.1016/j. microc.2011.05.014.

11. Zhilkina, V. Yu.; Marakhova, A. I.; Stanishevskiy, Ya. M. Qualitative and quantitative analysis of organic acids in mixture of multivitamin raw material. Drug development \& registration 2016, 1, 156-159.

12. Umarov, U. A.; Maslov, O. Y.; Kolisnyk, S. V.; Fathullaeva, M. Development and Validation of The Conductometric Titration Method of Quantitative Determination of Free Organic Acids in The Anise Fruits. European Journal of Molecular \& Clinical Medicine 2020, 7 (3), 3874 -3883.

13. Sochorova, L.; Torokova, L.; Baron, M.; Sochor, J. Electrochemical and others techniques for the determination of malic acid and tartaric acid in must and wine. Int. J. Electrochem. Sci. 2018, 13 (9), 9145-9165. https://doi.org/10.20964/2018.09.20.

14. Strömberg, N.; Sahlin, E. Determination of the short-chain fatty acid pattern in biodiesel using high throughput syringe solvent extraction and ion exclusion chromatography. Fuel 2012, 97, 531-535. https://doi.org/10.1016/j.fuel.2012.01.032.

15. The International Council for Harmonisation. Quality Guidelines. https://www.ich.org/page/quality-guidelines (accessed Jan 10, 2021), Validation of analytical procedures: text and methodology Q2(R1).

16. Державна фармакопея України: в 3 m., 2-е вид.; Державне підприємство «Український науковий фармакопейний центр якості лікарських засобів»: Харків, 2015; Т. 1

Received: 12. 12.2020

Revised: 14.01.2021

Accepted: 23.01.2021 